\title{
Waqf Making and Commercial Cemeteries: Religious Circulation and Commodification of the Economy of Giving"
}

\section{Amelia Fauzia}

Syarif Hidayatullah State Islamic University Jakarta

fter learning of some controversies, conducting interviews, and making a visit
to the Firdaus Memorial Park in West Java in 2016 - a place that some critics
have referred to as a luxury waqf cemetery - I came to realize that the name 'Firdaus' does not solely belong to this cemetery in Indonesia. In Maryland, USA, a waqf Muslim cemetery called Al-Firdaus Memorial Gardens has been in operation since 2008. Both cemeteries are relatively new and are managed under a modernized waqf system. Both observe almost the same simple, grassy type of burial plot resembling that which is advocated in Salafi teachings; they are commercial yet they aim that their profits be used for Islamic dakwa projects; and they both conduct fundraising for charitable activities. Yet they have no connection with, nor do they learn from, one another, and each one fails to realize that they have a 'sister' far away. In Islam the name 'Firdaus' refers to one of the names of Heaven that are mentioned in the Qur'an, so any Muslim institution could employ the term as a kind of prayer wish or invocation for those who have departed from this life that they may rest in Heaven. The two cemeteries might be connected via the circulation of ideas and practices of a number of contexts which may not be directly interconnected, but they are still linked by the underpinning idea of developing the old concept of waqf - the concept of Muslim endowments dedicated for charitable purposes - in the context of the practicalities of the contemporary neoliberal socio-economic climate. The ongoing and worldwide circulation of ideas and practices brought waqfs, one of the early forms of charitable institutions in the Islamic tradition, to be practiced across historical periods and into geographical regions such as Indonesia, which is relatively far from the traditional center of Islam in the Middle East.

\footnotetext{
* I would like to thank two anonymous reviewers who provided constructive suggestions to this article and to thank Cluster Religion and Globalisation, the Asia Research Institute, National University of Singapore for Research Fellowship from September 2015 to August 2018 which allowed me to conduct research on Islamic philanthropy. Fieldwork activities for this article were supported by the Asia Research Institute, NUS and Badan Wakaf Indonesia.
} 
In Indonesia, the practice of waqf experienced a gradual growth, in step with the expansion of Islam into the archipelago ${ }^{1}$ and the number of waqfs has steadily increased over time, appearing in five forms or purposes, namely in buildings for religious prayer (mosques and mushallas, these accounting for about 80 per cent of waqfs), schools, activities with a social purpose, cemeteries and agricultural land. ${ }^{2}$ The number of waqf cemeteries has always been small and the attention given to, as well as the studies made on, this type of waqf has been minor.

From the limited number of historical accounts in Indonesia, both before and during the nineteenth century, we see that the waqf-making of great buildings was mainly by rulers, wealthy families and religious leaders, this being a common picture throughout the Islamic world. ${ }^{3}$ A local tradition of voluntary works and donations (what is referred to in Indonesia by the term gotong royong) might have contributed to support the establishment of mosques on waqf estates, a tradition that has been preserved to the twentieth century, ${ }^{4}$ but since the point of high fervor of Islamic charitable activism from the fall of the New Order regime in Indonesia in 1998 (philanthropization), the practice of waqf has become increasingly popular alongside that of zakat. A combination of the effects of Islamization, modernization and ideas of poverty eradication and social justice has awakened the possibilities of charitable fundraising and that includes waqf. ${ }^{5}$ The neoliberal structure that has been adopted within Indonesia, especially after 1997 the monetary crisis, provided in turn an additional basis for modernization. Further, this article finds that modernization, the neoliberal and digital economy, and an Islamized urban life style have endorsed a new model of waqf; one

\footnotetext{
${ }^{1}$ See sections on "Mosques and the Waqf Traditions" (pp 89-93) and "the Development of Islamic Institutions through Sedekah and Waqf" (pp. 115-127) in A. Fauzia, Faith and the State, A History of Islamic Philanthropy in Indonesia (Leiden and Boston, EJ Brill, 2013). An earlier study that records an increase in the number of waqfs is R. Djatnika, "Les Biens De Mainmorte (Wakaf) A Java-Est." Ph.D. dissertation, École Des Hautes Études Et Sciences Sociales, 1982.

2 AA. Prihatna, et.al, Wakaf, Tuhan, dan Agenda Kemanusiaan: Studi tentang Wakaf dalam Perspektif Keadilan Sosial di Indonesia [Waqf, God, and humanitarian agenda: studies on waqf in the perspective of social justice in Indonesia], eds. TA. Najib \& R. Almakassary (Jakarta: CSRC, 2006). On the institution of waqf, see also AA. Prihatna et.al, Revitalisasi Filantropi Islam: Studi Kasus Lembaga Zakat dan Wakaf di Indonesia [Revitalization of Islamic philanthropy: case studies of zakat and waqf institutions in Indonesia], eds. I Abubakar \& CS Bamualim (Jakarta: PBB, 2005).

${ }^{3}$ A. Singer, Charity in Islamic Societies (Cambridge: Cambridge University Press, 2008).

${ }^{4}$ A Fauzia, Faith and the State, 89-92, 115-127.

${ }^{5}$ See A. Fauzia, "Islamic Philanthropy in Indonesia: Modernization, Islamization and Social Justice," Austrian Journal of South-East Asian Studies 10/2, (2017), 223-236. Important to note that vocabulary of "poverty eradication" may be too political for charitable agencies. For an example, IIROSA avoided poverty eradication programs in South Thailand and concentrated on safer projects. See R.A. Brown, "Saudi Charitable Impulse Abroad. The Coercive Power of Belief and Money in Thailand," in R.A. Brown \& J. Pierce, eds, Charities in the Non-Western World. The Development and Regulation of Indigenous and Islamic Charities, (London and New York, Routledge, 2013), 251- 275.
} 
that has shifted from the form of a traditional estate endowment from one person or family, into a cash waqf endowed by a number of people (waqif) coming together through various types of money transfer and financial digital applications, with each individual being able to start with a small amount as little as one dollar.

This post New Order charitable movement resembles what Atia has termed "pious neoliberalism" in which Islamic philanthropy has shown a compatibility between the expansion of the neoliberal economy and the aims of a pious society that "connotes a transformation in both religious practice and modalities of capitalism." ${ }^{6}$ Waqf (or its plural form, awqaf) has been explored for a range of possible economic and financial developments that include the "productivizing" of cemeteries. In this case the object of the waqfs were previously regarded as "dead properties," in the sense that they were difficult to make progress in and to earn profit from. In an unexpected move, a new form of cemetery attached to a waqf was created, inspired by the new trend of modern, luxurious cemeteries led by San Diego Hills Memorial Park, this park having started in 2008. Islamic charitable organizations began to create commercial Muslim cemeteries, combined with both old and new concepts of waqf-making in urban communities. The new concept of modern cemeteries is modified by charitable forms that benefit the poor and it resembles Salafi practices with regard to funeral rituals.

The Islamic charitable movement has been endorsed by modernist, reformist Muslims, some of whom have puritan-revivalist characteristics ${ }^{7}$ that have come to be identified as a distinct category in the last ten years and are generally referred to under the term Salafism. Salafis seek to live according to what they see as the authentic form of Islam that is based on the Prophet and the early generations (and this thinking also applies to the concept of burial), and they seek therefore to comply only with the Qur'an and the Sunnah - the practices of the Prophet - and to avoid any religious action that has no precedent in the time of the Prophet, these actions being seen as innovations. It is a type of Muslim religiosity that is growing worldwide, though in terms of strict adherence in Indonesia this group consists of less than $1 \%$ of the Muslim population. ${ }^{8}$ While practitioners have brought zakat discourse into the idea of the centralization by the state (mainly by Islamist and Salafi groups), ${ }^{9}$ waqf has been brought into the discourse of decentralization and developmentalism. Circulated narratives of waqf histories tend to negate good aspects of waqf management by the states, so that modernists tend to avoid centralization on the basis that there was no precedent for this in the period of the Prophet. ${ }^{10}$ The urban professional practice of Islamic philanthropy

\footnotetext{
${ }^{6}$ M. Atia, Building a House in Heaven: Pious Neoliberalism and Islamic Charity in Egypt (Minneapolis: University of Minnesota Press, 2013).

${ }^{7}$ A. Fauzia, Faith and the State, 3-4.

${ }^{8}$ J. Jahroni "The Political Economy of Knowledge: Salafism in Post-Soeharto Urban Indonesia," Ph.D dissertation, Graduate School of Arts and Sciences, Boston University, 2015, 7-8.

${ }^{9}$ A. Fauzia, Faith and the State, 213-256.

10 S. Joseph, "Waqf in Historical Perspective: Online Fatawa and Contemporary Discourses by Muslim Scholars," Journal of Muslim Minority Affairs 34/4 (2014), 425-437.
} 
has enhanced a new form of waqf cemeteries that follow an Islamic neoliberal trend and which, in their nature are, surprisingly, in conformity with Salafi teachings.

Modernism and the urban lifestyle have transformed the practice of waqf related to cemeteries. A number of questions, however, arise. How could waqf development in Indonesia give birth to these commercial waqf cemeteries that follow the Salafi practice of burial? What factors endorse the development of waqf-making? How is the idea of 'old' waqf being renewed to become relevant with various types of fundraising and finance, and with business, including the adoption of financial technologies? To answer these questions this article focuses on the development of waqf cemeteries in the Indonesian Archipelago over the last twenty years, looking at the circulation of waqf ideas and practices in the context of Islamic philanthropy.

This article takes two cases of commercial cemeteries that involve waqf, namely the Firdaus Memorial Park that we have previously mentioned, and Al-Azhar Memorial Garden, both located in West Java, with easy access for the citizens of Jakarta. ${ }^{11}$ The article provides a brief background on the contemporary practice of waqf in Indonesia and discusses the concept of "productive waqf" that has circulated and that has stimulated the development of this form of waqf. The article ends with a section that discusses factors contributing to the change in waqf making and the development of new waqf involving cemeteries, together with a conclusion. As the article refers to the commercial and economic aspects of giving, it does not study the economy of waqf. Instead, it studies social phenomena underlying the practice and development of waqfs that refer to teachings, social perceptions and practices, based on Islamic studies and Social History. The article uncovers the indirect impact that recent exploration in waqf making has had in popularizing waqfs in a way to move them from the domain of the practice of rich people into those of the middle- and even lower-income groups.

\section{Waqf Environment and Development of "Productive Waqf" in Indonesia}

The long history of Islam in the Indonesian Archipelago has led to the practice of waqfs, along with that of zakat, as being generally a community-based institution, relatively independent from the direct management by the state, albeit with minor exceptions. ${ }^{12}$ The role of the state, under the Ministry of Religious Affairs, is in facilitating and supervising practices of zakat and waqf as religious activities. For its part, the economy of waqf was not obvious, as most assets are consumable services and not (economic) investments. Given the level of high suspicion and fear toward the secular authoritarian state, which was sensitive toward disclosing details of the conditions of poverty within the country, the New

\footnotetext{
11 Fieldwork was conducted on several occasions between 2016 and 2017.

12 R. Djatnika, "Les Biens De Mainmorte (Wakaf) A Java-Est," and A. Fauzia, Faith and the State.
} 
Order's effort to modernize and mobilize the Islamic philanthropy sector failed. Added to that the worldwide growth of waqf studies in the twentieth century did not reach the Southeast Asia region. ${ }^{13}$ It is possible that the region was on the periphery in regard to the study of Islam and charity, and that the practice received less public attention.

The significant economic crises that have occurred since 1997 created an opening that gave rise to an Islamic philanthropy sector. In these crises the state could not afford to solve the problems of poverty, even though it has received assistance from the International Monetary Fund. The political reform that started in 1998 has brought Indonesia to a situation of a deeper level of neoliberal governance, and brought its people and the third sector to engage in welfare and in solving the problem of poverty from a neoliberal perspective. The accommodation of Islam in the reformed political constellation of the post-New Order period encouraged the participation of political Islam and the philanthropy sector into the arena of poverty eradication.

Studies on waqfs increased significantly in number from 2003, with a further increase since $2008 .{ }^{14}$ With a growing interest of developmentalism world-wide, the attention on the practices and studies of waqfs have revealed an enthusiasm for the potential of the instrument of waqf as one of the alternative sources for development and welfare. The movements toward modernization of waqf began in the 1980s, in places such as the Sudan, then Kuwait, and also in Qatar, and on to many countries. ${ }^{15}$ From this circulation and spread of ideas the term "productive waqf" was generated, to refer to the concept of the revitalization and modernization of the institution of waqf and the management of its resources in "productive" ways for generating greater benefit for welfare. ${ }^{16}$ In

\footnotetext{
${ }^{13}$ M. Hoexter, "The Waqf Studies in the Twentieth Century," Journal of the Economics and Social History of the Orient, Vol 41, no 4 (1998), 474-495.

${ }^{14}$ A. Fauzia, N. Almuin, T. Rohayati and EA. Garadian, Fenomena Wakaf di Indonesia: Tantangan Menuju Wakaf Produktif [Phenomenon of waqf in Indonesia: challenges toward productive waqf] (Jakarta: Badan Wakaf Indonesia, 2016), 65-91. My own exploration using the Indonesia National Library catalogue Onesearch to search books, articles, unpublished academic reports/research and archives records has uncovered 1,995 items with the title wakaf from 1926 to 2018, these items being dominated by books and unpublished academic theses. From 1990 to 2017 the increase in the collection is 1,250 per cent. The significant increase is after the Reformasi period. http://onesearch.id/ Search/Results?lookfor=wakaf\&type=AllFields\&limit=20\&sort=relevance, 20 February 2018.

${ }^{15}$ Monzer Kahf (Mundzir Qahf), one of the most frequently cited scholars on the idea of financing and productivizing waqf. One of the reforms he has advocated is through the revision, or specifically "contextualization" of classical fiqh. See "Towards the Revival of Awqaf: A few Fiqhi Issues to Reconsider", presented at the Harvard Forum on Islamic Finance \& Economics, Oct 1999, Harvard University. Url http://monzer.kahf.com/papers/english/FIQHI_ISSUES_FOR_REVIVAL_OF_waqf. pdf, last visited 10 May 2018.

${ }^{16}$ Monzer Kahf, "Financing the Development of Awqaf Property" The American Journal of Islamic Social Sciences 16/4 (1999), 39-66. He was a former ISNA director of finance and head of the division of IRTI-IDB. One of his books on the development and management of waqf has been translated into Indonesian with the title, Manajemen Wakaf Produktif [Management of productive waqf], (Jakarta: Khalifa, 2005).
} 
Indonesia, the idea has been spread at the national level since 2001, beginning with "productive zakat" and later "productive waqf."17

This institution of waqf has been regarded as "a sleeping giant," due to its large resources, potential economic benefit and its inherent model of sustainability, but a giant that has remained unused or under-used. Many waqf estates have been left unattended, such that they have become "dead" properties in the real sense of the meaning of the Arabic term waqf (i.e., to stop, to halt), and many scholars, practitioners, as well as senators, have supported the idea of productive waqf as a subject of national interest in order to realise and maximize its potential. ${ }^{18}$ This idea has brought into being the issuance of the Waqf Law (2004), following the Zakat Law (1999 and 2011), including the use of the term "productive waqf."

The Waqf Law states that, "waqf is a religious institution which has economic potentials and benefits that need to be managed effectively and efficiently for the purpose of rituals and advancing public welfare." ${ }^{19}$ And it adds that "one of the strategic ways to enhance public welfare is the need to enhance the role of waqf as a religious institution not only as a medium for ritual and social purposes, but also as a source of economic power that could progress the public welfare; therefore its usage needs to be developed based on the principle of sharia." ${ }^{20}$ Behind the issuance of the Waqf Law is the idea of

\footnotetext{
${ }^{17}$ About productive zakat see K. Retsikas, "The Promise: Islamic Micro-Finance and the Synthesis of Time," Deleuze Studies 9/4 (2015): 475-502. Researchers at Syarif Hidayatullah State Islamic University had seen the movement and wrote a subsection entitles "productive waqf" in A. Fauzia, et.al, Filantropi Islam \& Keadilan Sosial: Studi tentang Potensi, Tradisi dan Pemanfaatan Filantropi Islam di Indonesia [Islamic philanthropy and social justice: studies on potential, tradition and utilization of Islamic philanthropy in Indonesia], eds by I. Abubakar and CS. Bamualim, (Jakarta: CSRC, 2006), 72-77.

${ }^{18}$ Starting from 2002 an increasing number of circulated publications have discussed the economic function of waqf such as in Wakaf untuk Kesejahteraan Umat [Waqf for the Welfare of the Umma] by Imam Suhadi (Yogyakarta: Dana Bhakti Prima Yasa, 2002), A. Djuanidi and T. Al-Asyhar, Menuju Era Wakaf Produktif: Sebuah Upaya Progresif untuk Kesejahteraan Umat [Towards the Era of Productive Waqf: a Progressive Effort for the Welfare of the Umma], (Jakarta: Mitra Abadi Press, 2005). Publications of the Ministry of Religious Affairs on waqf have changed their emphasis from matters of administration and fiqh to those management and productive waqf. As an example of this see: Strategi Pengembangan Wakaf Tunai di Indonesia [Strategies for the Developing of Cash Waqf in Indonesia], (Jakarta: Direktorat Pengembangan Zakat dan Wakaf, 2005). Seminars on the economy of waqf and its productivity have been organized by universities and also government agencies. An international workshop on the subject of productive waqf was organized in Batam by IIIT and the Ministry of Religious Affairs, 7-8 January 2002. Since then, a number of seminars on productive waqf have been held. One example is the "International Conference on Waqf and Economic Growth" in Jakarta 2016. The neighboring country, Singapore, supported the idea and held the "Singapore International Waqf Conference" in March 2007. At this conference, Singapore's Senior Minister, Goh Chok Tong spoke on the "integration of awqaf into Islamic finance," with the aim that "Singapore become a center for the development of waqf." See BIZ Review, 21/2007.

${ }^{19}$ Consideration, the Waqf Law 2004. See the official copy at https://kemenag.go.id/file/dokumen/ UU4104.pdf.

${ }^{20}$ Explanation of article 1, The Waqf Law 2004.
} 
reviving its "dead" and "not-productive" assets, with the movement of productive waqfs and cash waqfs. Development of waqf properties should be implemented in productive ways ${ }^{21}$ for the following reasons.

The practice of waqf in society has not been implemented in good order and in ways that are efficient, so that there are many cases where waqf assets have not been properly managed, as they should have been. By contrast they have been left unattended, or taken illegally by a third party. These outcomes have happened as a result of negligence and the presence of unskilled waqf managers (nazir) in managing and developing the assets, but also the unconcerned attitude of society and the lack of a proper understanding that the assets should be protected for the public welfare according to the aims, functions, and designations of the waqfs.

In general, the scope of waqf so far understood is limited to the unmovable properties such as lands and buildings. According to this law, the waqif could endow some of their movable wealth, whether material or immaterial, namely cash, gold, securities, cars, intellectual properties, rights of rent and other movable objects. ${ }^{22}$

An attempt to develop waqfs to become "productive" has meant commercializing the assets of waqf properties in order to derive profitable revenues for supporting Islamic institutions and the waqfs themselves. Among the ways are "...by means of collection, investment, capital investment, production, trade, agribusiness, mining, industry, technology development, building construction, apartments, supermarkets, shops, offices, educational facilities, health facilities, and other businesses which are not against the sharia." 23 This move brings the priorities of piety and profitability together, something encouraged by both "pious neoliberalism" and "the spiritual economy."

The Waqf Law gave birth to National Board of Waqf (Badan Wakaf Indonesia - BWI) in 2007 to supervise, facilitate and develop the activities of waqf. This institution brings a heavy burden on the endorsement of the "productive waqf" - while it does not have much political power, nor resources, nor a systematic approach under the complex Indonesian political and legal system and within a "noisy" democracy. However, the institution has at least provided a clear endorsement for philanthropy organizations to utilize the waqf sector supporting the neoliberal economies and in the last few years, Indonesian government agencies, such as the Bank of Indonesia, have endorsed the idea of productive waqf by sponsoring public and scholarly events, and has developed further concrete projects to use the institution of waqf for development. ${ }^{24}$ In concert with a global leaning

\footnotetext{
${ }^{21}$ Article 43, the Waqf Law 2004.

22 Explanation of article 1, the Waqf Law.

${ }^{23}$ Article 43, verse 2, The Waqf Law 2004.

${ }^{24}$ One example is ISEF, an annual Indonesia Sharia Economic Festival, organized by the Bank of Indonesia since 2014. See https://www.bi.go.id/id/isef/tentang-isef/Contents/default.aspx, last visited 07 May 2018. The Bank of Indonesia sponsors the study of the Waqf Core Principle that has invited international waqf institutions since 2014.
} 
Table 1. Total number of waqf estates in Indonesia over a number of years

\begin{tabular}{llll}
\hline Year & Total number & & \\
\hline 2006 & 404,676 & Surface area in m2 & Certificated \% \\
2010 & 415,980 & $1,849,771,348.42$ & 75 \\
2012 & 420,003 & $2,171,300,341.74$ & 67 \\
2013 & 428,535 & $3,492,045,373.75$ & 67 \\
2014 & 435,395 & $3,993,536,769.00$ & 67 \\
& $4,142,464,287.90$ & 66 \\
\hline \hline
\end{tabular}

Sources: Directorate for Guidance of the Islamic Community, and also from the Directorate for Waqf, Ministries of Religious Affairs Republic Indonesia, published in the years 2007, 2011, 2013, 2014 , and 2015.

*Islamic Religious Offices (Kantor Urusan Agama) recorded data of waqf assets limited to land, reported by nazir of waqfs. From my own observation, there are at least 20,000 waqf estates which are unrecorded by the Offices of Religious Affairs. However, many of these deeds have not been reported/registered to the National Land Agency (to get certificates of waqf), due to the complexity of the system of bureaucracy.

toward religion and development, international agencies, such as the International Development Bank (IDB) and the United Nations Development Program (UNDP) have started to support a number of projects for piloting productive waqfs. ${ }^{25}$

However, one problem in the modernizing of waqf is the inadequacy and the question of accuracy of data. Existing data refers only to estates as "unmovable" properties. Table 1 shows an increase in waqf assets (column 2) but the percentage of assets getting certificates of waqfs from the National Land Agency (Badan Pertanahan Nasional - BPN) has decreased (column 4). In 2014, 34 per cent of waqf land has not been reported to the agency. The religious offices do not have reports of waqf management, nor data for cash waqf and other "movable" waqfs.

In the last two years, the Ministry of Religious Affairs has been updating the assets of waqf estates. An updated, verified number $(335,718)$ shows that prayer buildings (mosques comprising 45 per cent and mushallas 29 per cent) form the highest percentage, followed by schools (10 per cent), Islamic boarding schools or pesantren (3 per cent), waqf estates for social purposes (8 per cent), and waqf cemeteries (4.6 per cent). ${ }^{26}$ Each region has different percentages according to the local context. For example, in Jakarta the number of waqf cemeteries is very limited; the figure being 0.3 per cent (from a total of 5,661 waqf estates), which is far below the national percentage. In fact, the availability of public cemeteries is also insufficient in big cities in relation to the rate of population growth. The scale of this can be measured by the number of reports that indicate that the shortage of cemetery sites is at the level of an

\footnotetext{
${ }^{25}$ In addition to projects, the endorsements have been undertaken through close collaborations. For an example, UNDP signed an MOU with the Indonesia Waqf Board for the SDGs http://www. id.undp.org/content/indonesia/en/home/presscenter/pressreleases/2018/1/promoting-waqf-forsdgs--bwi-undp-signed-an-mou.html?cq_ck=1516970682583.

${ }^{26}$ Information system of waqf (Sistem Informasi Wakaf, abbreviated as SIWAK), Ministry of Religious Affairs, http://siwak.kemenag.go.id/, visited 17 February 2018. The Ministry has a target to calculate Islamic boarding schools with waqf status so the database has set boarding schools as a separate type from other schools.
} 
emergency. ${ }^{27}$ The two case studies presented later in this article also mention the shortage of cemeteries as one of their significant concerns.

With almost half a million registered waqf estates and a growing number of cash waqfs, the transformation into productive waqf looks promising. However, the fact that the majority of waqf managers (nazir), either hold to a strict interpretation of traditional Shafi'i fiqh, have no managerial skills or have no available time to manage waqf, works against that assumption. ${ }^{28}$ A Dutch scholar, G. F. Pijper, has reported problems related to the principles of "being unchangeable" and "having perpetuality" resulting in people being afraid to renovate the assets of waqfs so that in the end many are left broken and unused. ${ }^{29}$ To date, such a fiqh-based problem still exists since the majority of waqf are within the traditionalist mainstream domain that does not engage very much with the neoliberal economy. There is a gap between the traditionalist practice of waqf and urban modernist-reformist practitioners, who tend to refer to idealized historical narratives which to some extent ignore the complexities of waqf. ${ }^{30}$

This productive waqf phenomenon is not only an example of "Marketing Islam,"31 but it also reveals the complexities of philanthropization that involve professionals, the government, development agencies, and the charitable organizations, in developing and reviving waqf by employing every possibility within the theories of (neoliberal) economies whilst adapting these to the sharia. This new form of waqf-making may not seem something that we would consider amongst the "spiritual economies,"32 since the assets of the waqf itself are regarded as commodities that work as a target for the neoliberal economy. The "productive waqf" follows what scholars have referred to as "Islamic capitalism" or "ethical capitalism" and, more relevantly, have matched with the concept of "pious neoliberalism" as well as that of a "market morality." ${ }^{3}$ The pro-

${ }^{27}$ The following examples from the news media speak to these issues: "No more space in C. Jakarta Cemeteries" The Jakarta Post, 12 March 2011, http://www.thejakartapost.com/news/2011/03/12/ no-more-space-c-jakarta-cemeteries.html visited 02 February 2018, and Imam Buddy Utomo, "Ini Solusi Kekurangan Lahan Makam" [This is the Solution for the Shortage of Cemetery Sites], published 28 August 2013, SindoNews, https://metro.sindonews.com/read/776190/31/ini-solusi-kekurangan-lahanmakam-1377617166.

${ }^{28}$ A. Fauzia et al, "Fenomena Wakaf Produktif di DKI Jakarta" [Phenomenon of productive waqf in Jakarta], unpublished research, Jakarta, Badan Wakaf Indonesia, 2012.

29 G.F. Pijper, "Afbraak van Moskeën," Oudheidkundig Verslag 1930, Koninklijk Bataviaasch Genootschap van Kunsten en Wetenschappen (Batavia-Centrum, Albrecht \& Co, 1931), 240-242.

${ }^{30}$ S. Joseph, "Waqf in historical perspective.

31 A.S. Jahar, "Marketing Islam through Zakat Institutions in Indonesia," Studia Islamika, 22/3 (2015), 405-442.

32 D. Rudnyckyj, "Spiritual Economies: Islam and Neoliberalism in Contemporary Indonesia," Cultural Anthropology 24/1 (2009), 104-141.

33 R. Brown, "Islamic Endowment and the Land Economy in Singapore, the Genesis of an Ethical Capitalism, 1830-2007," South East Asia Research 16/3 (2008), 343-403. On Capitalism and Islam, see Oxford Islamic studies online, http://www.oxfordislamicstudies.com/article/opr/t125/e408. M. Çizakça, Islamic Capitalism and Finance: Origins, Evolution and the Future (Cheltenham, Northampton: Edward Elgar Publishing, 2011). See chapter 4 discusses Waqf of stocks, and Islamic insurance (takaful). 
ductive waqf works as "both religious social goals and profit and revenue creation,"34 which are re-embedded in neoliberal market actions within a pious society. ${ }^{35}$ While the neoliberal structures described in this article are mainly seen as a positive means to ensure the development of waqf or Islamic philanthropy in general, it does not mean this will end in positive impacts in the field. In fact, the growth of charities under a neoliberal structure in ten Western Asian, specifically Arabic, countries has led to legalization and statism. ${ }^{36}$

The way in which productive waqf has been applied in Indonesia shows a tendency toward "pious neoliberalism" and, at the same time, an example of "market morality" in which religion is being utilized for the developing or creation of waqf-making that is not restricted or limited. In this way, charitable organizations duplicate two growing trends: the first is the business of commercial cemeteries to combine with waqf formation and profit-making, and the second is the typical pattern of funeral and cemetery architectures which are beautiful, well-managed, of a high standard, and saleable to urban middle-class Muslims. Here, the rhetoric and "aesthetic of the market are mobilized as a means to rationalize the giving" 37 and the adaptation of waqf-making, which is heavily focused on profit and revenues, directly or indirectly, is legitimized by charity and the interest in welfare for the community. A "Salafi-friendly" type of cemetery - one which has been widely discussed and circulated in online sources - fits with the growing trend of commercial cemeteries, not only within Indonesia but also beyond. However, although this development of productive waqf seems to run smoothly, hidden tensions remain between modernist-reformist and traditionalist adherents - tensions which, in Davies' words, reflect "complexities between religion and philanthropy in religious philanthropic world." 38

\section{The Waqf Movement and the Economy of Giving: Firdaus Memorial Park and Al-Azhar Memorial Garden}

News that was circulated on the brand new concept of a commercial cemetery became the direct impetus for Muslims in Indonesia to establish commercial cemeteries that were exclusively for Muslims. Both the initiators of Firdaus Memorial Park (FMP) and Al-Azhar Memorial Garden (AMG) refer specifically to San Diego Hills Memorial Park and Funeral

\footnotetext{
${ }^{34}$ R. Brown, "Islamic endowment," 344.

${ }^{35}$ F. Osella \& D. Rudnyckyj, "Introduction: Assembling Market and Religious Moralities," in Religion and the Morality of the Market, eds. D. Rudnyckyj \& F. Osella (Cambridge, Cambridge University Press, 2017), 1-28, 2 and M. Atia, Pious Neoliberalism.

${ }^{36}$ B. Challand, "Comparative Perspective on the Growth and Legal Transformations of Arab (Islamic) Charities," in R. Brown \& J. Pierce, Charities in the Non-Western World. The Development and Regulation of Indigenous and Islamic Charities, (London and New York, Routledge, 2013), 293-390.

${ }^{37}$ F. Osella, "Poor Muslim cannot be a good Muslim: Islam, Charitable Giving and Market Logic in Sri Lanka," in Religion and Morality of the Market, D. Rudnyckyj \& F. Osella, 217-239.

38 T.J. Davies, "Introduction", Religion in Philanthropic Organizations: Family, Friend, Foe? Eds, Davies, (Bloomington: Indiana University Press, 2013), i-xxi, xiv.
} 
Homes, a high-class private cemetery (with luxurious facilities such as a hotel, a restaurant, a swimming pool, an eight-hectare lake, and a helicopter pad), established in a 500 hectare park by the Lippo Group, one of the biggest real estate companies in Indonesia and belonging to the conglomerate Muchtar Riyadi. ${ }^{39}$ Adopting its concept from two wellknown memorial parks in California, the emergence of San Diego Hills was quite a shocking innovation compared to the cemeteries that had been existing in the country up to this time, cemeteries which are mainly disorganized, and not beautiful.

Just like commercial housing estates, the San Diego Hills Memorial Park offers burial sites for three faith traditions: for Christians, for followers of Chinese religions, and for Muslims. ${ }^{40}$ The main Muslim site is named the Five Pillar Garden - a name that reflects the five pillars of Islam - and is divided into five clusters. Its design is creative yet is beautiful and strongly based on Islamic teachings. ${ }^{41}$ By strictly following one particular stream of interpretation and by creating affordable individual burial sites, this park has attracted Muslims, and that interest was not affected by public controversy and criticism, nor even by a fatwa from the Indonesian Council of Ulama (Majelis Ulama Indonesia - MUI) declaring it as haram. ${ }^{42}$ In fact, the number of Muslims who bought plots and have been buried there is not small. ${ }^{43}$ Later both Firdaus and Al-Azhar also received public criticism, although not as strong as that leveled at San Diego Hills, perhaps because this business is owned by people from the Chinese minority in Indonesia. ${ }^{44}$ Later,

\footnotetext{
39 See its website http://www.sandiegohills.co.id/.

${ }^{40}$ http://www.sandiegohills.co.id/wf/pContentLvl2.aspx?t=9, last visited 13 May 2018.

${ }^{41}$ Its designer is Mona Siddiqui, a well-known professor of Islamic studies (previously at Glasgow University and recently at the University of Edinburgh's School of Divinity.)

42 Fatwa no 9 issued on 20 February 2014 states that the "sale and purchase, and business land for the benefit of a luxurious grave which contains elements of tabzir [wasting money] and israf [excessive] is forbidden." Resistance is mainly based on the sharia argument as well as ethical and commercial reasons. Many refer to the fatwa of the MUI that underlies the point that excess in the purchasing burial sites is unethical, and mixing with other non-faith cemeteries is prohibited. Muhammadiyah also supported this fatwa. https://www.republika.co.id/berita/nasional/umum/14/ 02/26/n1lx1x-muhammadiyah-sepakat-fatwa-haram-pemakaman-mewah.

43 The management of San Diego provides general figures but did not want to disclose the percentage or detail numbers due to sensitivities over the business. However, if we consider the 8,274 burials that took place in 2016, obituaries with Muslim names such as "Muhammad" and "Fatimah," are numerous. Muslims from higher class positions in society, and from secular backgrounds, such as Endang Rahayu Sedyaningsih (Minister of Health, who was buried in May 2012) could accept this concept of a cemetery, while Muslims from rural and santri backgrounds would face sociological burdens to buy sites in this cemetery.

${ }^{44}$ See one of the opinions published in Kompas, F. Mu'adz, "Haramnya Bisnis Kuburan Mewah," http://www.kompasiana.com/advokat-faridmuadz/haramnya-bisnis-kuburan-mewah_552faa6c6ea 8343d128b4582 and "Tiru Kuburan Cina, Al Azhar Jadikan Kuburan Sebagai Ajang Bisnis", Voice of Al-Islam, 27 February 2013, https:/www.voa-islam.com/read/indonesiana/2013/02/27/23416/ tiru-kuburan-cinaal-azhar-jadikan-kuburan-sebagai-ajang-bisnis/\#sthash.DvraNoos.dpbs, VOA is a conservative Muslim channel. Its abbreviation is aimed at counterbalancing the Voice of America.
} 
however, each of them received support from Islamic organizations, including from MUI. ${ }^{45}$

The idea of a Muslim memorial park also finds acceptance among the Muslim middle class and their organizations, who sought to create the same idea although, in this case, by creating cemeteries that are solely for Muslims, not expensive, and that even have a charitable purpose. Activists of the Sinergi Foundation and the Salman Foundation, both from the Bandung area in Java, have strongly criticized the commercialization of cemeteries that do not offer low price plots, nor cater for the needs of the wider public, especially the poor, and yet still use the concept of waqf to describe their projects. Another concern expressed by activists is in reference to the non-sharia practice of the cemeteries, one of these being that there is no space between sites so that people unintentionally sit or step on another person's burial site. Salman launched its "Wakaf Makam Salman" in 2013 for opening in 2014 intended for providing facilities for their own members and also for the general public. ${ }^{46}$ Unfortunately, it stopped the program in 2015 , lacking capital to run the cemetery professionally, and because of an insufficient number of buyers or endowers. Just two Muslim memorial parks - Firdaus Memorial Park and Al-Azhar Memorial Garden - remain in business to date. Each of them operates a commercial financial mechanism in their own way to keep the park beautiful while supporting the poor, either by providing free burial sites or by providing more waqf assets.

\section{Firdaus Memorial Park}

The idea of "productive" waqfs, information on the shortage of cemeteries, and the reality that the poor face problems in obtaining spaces in cemeteries, are all issues that came to form the background for the activists of the Sinergi Foundation to initiate a park like San Diego Hill, but one that provides benefit for Muslim institutions and the poor. The former chief executive of Sinergi Foundation, Asep Irawan, related his own experience that took place once in the middle of the night in 2009. He happened to be at his office when a young couple knocked on the door and asked for his help. The mother was holding a boy who was weak and had difficulty in breathing. He drove them as quickly as possible to the nearest hospital but the doctor later declared the child to be dead. Feeling responsible, he drove them that night back to their rented accommodation and helped them prepare for the funeral in the morning. However, the neighborhood chief and mosque manager told him that the family could not bury the boy in the local public cemetery due to their status as non-residents of Bandung city.

\footnotetext{
45 At the present time criticism has lessened. This is due to a change in the position of MUI, from prohibition (in 2014) to giving permission and recommendations in support of Al-Azhar and Firdaus. The argument that the two cemeteries are not "luxurious" is well accepted. In fact, Firdaus Park has been backed by MUI in the West Java region who issued a recommendation to support it. Al-Azhar has been backed by the Muhammadiyah organization.

46 "Taman Makam Salman untuk Umat Muslim" http://salmanitb.com/2013/09/25/panitia-pembangunantaman-makam-salman/, accessed 25 August 2015.
} 
After negotiation, the burial was permitted but they still had to pay Rp600,000 (USD45). This is a regular payment for a burial in Bandung, but a fee that this family could not afford. Asep called his office, who later agreed to pay the fee. ${ }^{47}$ Years later, Asep found that this incident was not one he could easily forget. Later a momentum was created through the controversy on luxurious cemeteries that enabled him to push forward his idea on creating a waqf cemetery that combined the concept of waqf from the rich, investment, and free cemeteries for the poor.

Kyai Miftah Farid, a board chief of the Sinergi Foundation, named the cemetery Firdaus Memorial Park, the name itself suggesting a combination of Islamic and modern values. The Sinergi Foundation uses the English language and popular terms in its branding as its core constituency is formed of Modernist Muslims (consisting of academics, religious scholars, a business person, and an entrepreneur), specifically those who are close to the Islamist ideology. The foundation was initially one of the branches of the Dompet Dhuafa, a leading Islamic charity organization centered in Jakarta. The branch itself was established in 2000, and was mainly focused on providing services in health, through free maternity clinics, and education, through scholarships. Up to 2008, it received an operating budget from the Dompet Dhuafa and was known as Dompet Dhuafa Bandung. In 2009, with the boom in waqf, it slowly transformed itself to focus on "productive waqf," following the successes experienced by Majlis Ugama Islam of Singapore (MUIS) who own hotels, rental houses and other investments under their waqf portfolio. ${ }^{48}$ The foundation created the program known as WaqfPRO99 and later they became independent from the Dompet Dhuafa.

Their campaign for productive waqf has experienced a gradual success as a result of at least two factors. First, the foundation has a strong Islamic legacy, as the chief of the board is a well-known ulama in Bandung who sits as the chief of MUI of West Java. Kyai Miftah has a Ph.D from Syarif Hidayatullah State Islamic University, Jakarta, and is a professor at the Institute of Technology of Bandung. The foundation also adopted something of the legacy of Majlis Ugama Islam, Singapore, given that the policies they have employed have been regarded as successful in the matter of productive waqfs. Secondly, the foundation gained the trust of middle-income communities through its published reports and publications (with the principle of transparency and accountability); through its innovations that combine waqf with timely

\footnotetext{
${ }^{47}$ Interview with Asep Irawan in Bandung, 24 November 2015 and 01 December 2016. The story was also mentioned in many publications of the Sinergi Foundation and the Firdaus Memorial Park, including in a paper presented by a recent director of Sinergi Foundation in a conference on Islamic philanthropy. I. Rachmalia, et al, "Issues of Cemetery Management in Indonesia and Emergency Solutions Based on Waqf," unpublished paper, $5^{\text {th }}$ South East Asia International Islamic Philanthropy Conference, 14-16 February 2017, Center for Islamic Philanthropy and Social Finance of University Technology Mara, Melaka, Malaysia.

${ }^{48}$ Interview with Asep Irawan, Bandung 2015 and 2016. The success of MUIS in these matters has been widely publicized, including in Indonesia, with some visits of Indonesian ulama and academics to the MUIS office in Singapore, and through a range of publications.
} 
issues (such as a concern for the environment) with various fundraising exercises and investments; and through the use of financial technologies. In 2012 it launched the Firdaus Memorial Park Program, which was inaugurated in December 2013. Abdullah Gymnastiar, a well-known ulama, is among those who signed the park's inscription.

The concept of the Firdaus Memorial Park is as follows: the Foundation sets an area for a cemetery of which it offers burial plots for people to buy and to endow as waqf. For an example, someone who is interested to become a waqif needs to pay 15 million (for the purchase of the land) and 1.5 million rupiah (for the administrative and acquisition process). The person will receive two burial sites dedicated for him or her, or the family, and another two burial sites for the poor, to a total of eight square meters, all located in the area of Firdaus Memorial Park. The person then endows the burial plots as waqf and entrusts their management to Sinergi Foundation (and therefore, Kyai Miftah) as nazir. The waqf and purchase deeds are made before a notary. Later the Firdaus staff will proceed to the Land Agency to obtain certificates of waqf. The buyer/waqif is expected to donate a cash waqf to support various business projects such as boutiques, restaurants, and an agricultural farm. The Firdaus Park intentionally planted "productive" trees and horticulture in a separate area that could give benefit to local farmers, and has received income from visitors as an educational park. ${ }^{49}$ The Foundation has referred to this scheme as a combination of productive waqf (namely, with respect to the agriculture) and social waqf (namely through providing free burial sites for the poor). ${ }^{50}$

Moreover, the foundation plans that one plot of the burial site could contain up to three bodies (from one family) set at different depths, or one site could be used to bury other corpses after a certain number of years on the understanding that the "previous deceased had decomposed," which according to Asep and Rachmalia, follows the practice of Al-Baqi cemetery in Medina and is deemed permissible both by classical and contemporary scholars. ${ }^{51}$ At Firdaus, all burial plots should follow the same pattern, namely that they be 10 centimeters high from the ground, covered just with grass, use modest tombstones, and have space for walking alongside (see figure 1 below). In this way, the park claims to be both environmentally friendly yet also sharia-compliant.

The Firdaus site plans to have graveyard plots of 31 ha located in Cikalong Wetan, West Bandung. By 2016 it had secured about seven hectares for sale for the burial grounds, and the construction of a mosque; for a pesantren and other productive endowments such as visitor facilities; and farms, and walking tracks. Its prices for the burial sites that it offers started from Rp15 million in February 2016 (an increase from Rp10 million in the previous year), excluding 10 per cent administration fee. By 2016

\footnotetext{
49 The farm area consists of a small location downhill from the cemetery area. When I visited there, there was a fishpond with a shed for hens, and a horticulture plot about $100 \mathrm{~m}^{2}$ wide. The FMP established a number of wooden gazebos and built access to the whole area of the garden for educational programs.

${ }^{50}$ Interviews with Asep Irawan, brochures, and information from its website.

${ }^{51}$ Rachmalia et.al refers to the hadith narrated by Aisyah. So far, the idea of combining burial plots has not yet been exercised, as most waqif and their families are still alive.
} 


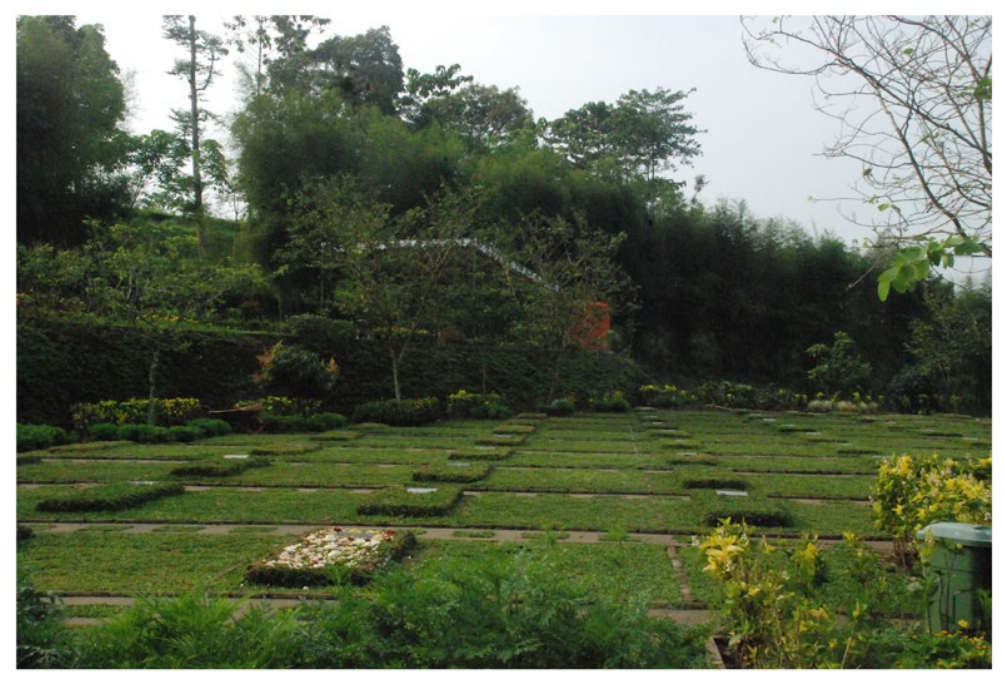

Figure 1. Burial sites at Firdaus Memorial Park. Photograph by the author.

the park had sold 1,045 burial sites, and it housed 41 bodies, four of them being from the poor. The price of a plot in the burial site is more affordable compared to the San Diego Hills, but the price still shows that it targets middle-income Muslims who have a surplus of money and who want to perform charity. The park received a recommendation from the MUI dated 29 August 2014, signed by the chief and secretary of the fatwa commission endorsing the claims of the park that it has followed sharia principles. ${ }^{52}$ Even though the practitioners of the Sinergi Foundation do not lean much towards the Salafi type of Islam, their modern waqf cemetery follows the growing middle-income trend that to some extent is Salafi-friendly, such that its sister in Maryland US, and the practice of the San Diego Hills, and Al-Azhar Memorial Garden follow the same trend.

\section{Al-Azhar Memorial Garden}

Al-Azhar Memorial Garden (AMG) was initiated as a response to the same impetus as the Firdaus Park, namely the presence of Muslim burial sites at San Diego Hill. Muhammad Rofiq Lubis, former director of Wakaf Al-Azhar, saw that this cemetery was crowded with Muslim buyers. He recalled the stories that many cohorts of Al-Azhar asked about the new, and controversial, burial and proposed that Al-Azhar follow the same format but in this case just for Muslims. ${ }^{53}$ Al-Azhar is a large organization that

\footnotetext{
52 Recommendation Rek-328/MUI/VIII/2014. It says that the fatwa commission received more thorough information (from observation, presentation, reports), that the Firdaus Memorial Park, is 1) using the waqf contract; 2) the cemetery is public, and not exclusive; 3) that it is targeted for Muslims in the surrounding area, including the poor; 4) that it is managed by principles of simplicity, without excess (tabzir and israf), and 5) the cemetery is not mixed with non-Muslims. Therefore, MUI recommends this and requests all parties to support this program as part of dakwa.

53 Interview, conducted 20 August 2016.
} 
owns many sub units, from elite schools, a university, religious gatherings (majlis tak$\mathrm{lim}$ ), and a charity organization, through to many businesses, all under the Islamic School Foundation (Yayasan Pesantren Islam) of Al-Azhar, which is commonly abbreviated as YPI Al-Azhar. ${ }^{54}$ Its businesses include tours and travel, and hajj services, as well as funeral services that are restricted to providing only the bathing, shrouding, committal and escorting of bodies to any specified cemetery. For Al-Azhar, the proposal to have a beautiful and exclusive cemetery is not difficult to achieve, and the creation of the burial site of AMG complements its existing funeral services that were started in 2011. ${ }^{55}$ The way Al-Azhar responded and established the cemetery was different from that of Firdaus, which is directly under a charitable foundation. AMG is taken care of by the Berkah Gemilang, a corporation that deals with business of estates and constructions under the development and enterprise department of YPI Al-Azhar, and the marketing for this memorial garden is carried out by the Nusantara Prima Sukses Sejati company. The location of the cemetery is in Karawang, near to other luxurious cemeteries such as San Diego Hills and Lestari Memorial Park, where it has direct toll road access from Jakarta.

AMG was created as a business unit, and not as a waqf cemetery. It is a commercial cemetery for Muslims, the profit from which is returned to the Al-Azhar Foundation, and to support the establishment of a free waqf cemetery for the aged poor in Jakarta and to support the productive waqfs managed by the Wakaf Al-Azhar. Even though AMG is not a waqf cemetery, its aims and context are deeply embedded in the idea of charity and endorsed as a kind of branding in the division of Wakaf Al-Azhar. This division was created in July 2010, "to develop and manage productive waqf in order to support activities of education and dakwa." ${ }^{56}$ Moreover, it states that,

...its birth was inspired by the waqf of Al-Azhar University, Cairo, Egypt, which was advanced progressively by managing the PRODUCTIVE WAQF in the form of hospitals, apartments, hotels, plantations, and by managing various businesses so it gave scholarships to 400,000 students, incentives to 11,000 lecturers and has been able to enhance dakwa and to send ulama overseas. With the support from all the affiliates, YPI Al-Azhar seeks to develop PRODUCTIVE WAQF as a means to empower the economy of the umma for the future of education and dakwa. ${ }^{57}$

\footnotetext{
${ }^{54}$ YPI was established in 1952 as an educational and dakwa foundation. In 1953-8 it built a mosque named as the grand mosque of Kebayoran, of which Prof Dr. Buya Hamka was the chief imam. In 1961 the Grand Shaikh of Al-Azhar, Mahmud Shaltout, visited the mosque and changed its name to Al-Azhar. Al-Azhar communities are typical of modernist Muslims.

55 See detailed explanation, including background, vision and mission in http://alazharmemorialgarden.co/al-azhar-memorial-garden/.

56 https://wakafalazhar.wakafonline.id/hal/9-Tentang+Kami/.

${ }^{57}$ Capitalization is from the original text. The Al-Azhar University of Cairo has been regarded as one idealized model for productive waqf.
} 
Various "productive" waqfs are linked to AMG, through the profit from its garden business and through a bundle purchase of a burial site. The sale of the burial sites is also bundled together with "waqf of wasiya sharia insurance policy" (Wakaf Wasiyat Polis Asuransi Syariah) as follows (see its promotional launch in figure 2). Someone who gives his or her insurance coverage of less than 250 million rupiah will receive and endow (at the time of claim) waqf khairi with his or her name, get a burial site at AMG and funeral facilities. In the case of packages with more than 250 million, 500 million, and one billion commitments, the waqif will receive burial sites (one, two or more) and burial sites for the poor (all of these including funeral services), and waqf khairi endowed in his or her name. This is endowing the future coverage money of life insurance as a charity to an institution, declared in a will (a wasiya) and with a certificate of cash waqf, as well as the police insurance. ${ }^{58}$ For an example, someone purchases an insurance policy, for which he or she will pay an agreed amount (premium) for a certain period (such as one and half million rupiah per month for 10 years), and the insurance company will give the coverage money (such as 1 billion rupiah) when the person dies or reaches a certain age. The amount of coverage will be given as a cash waqf. ${ }^{59}$

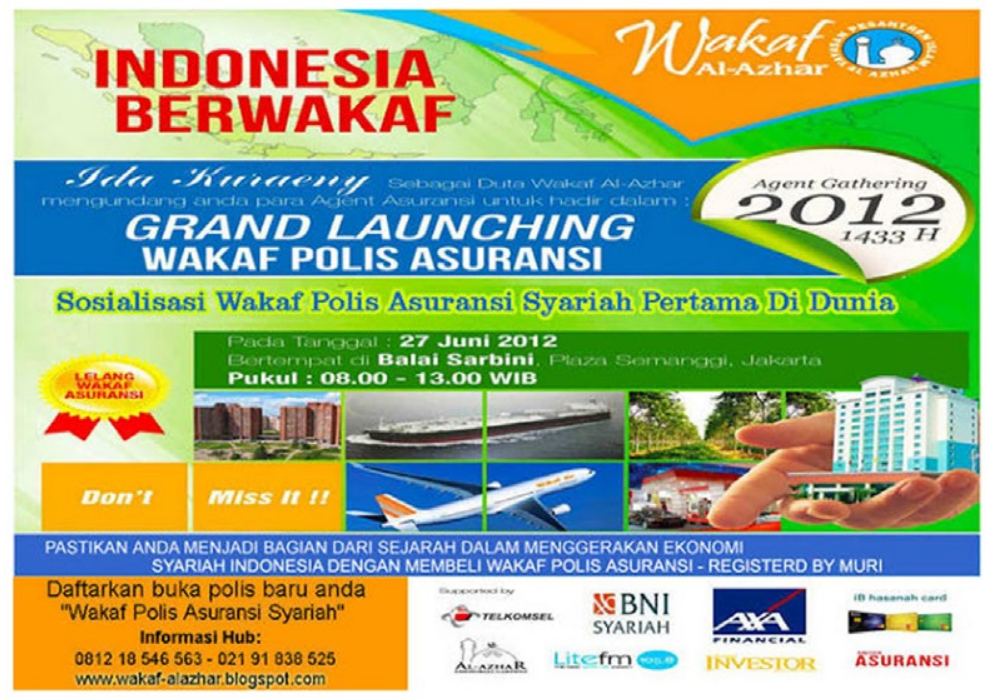

Figure 2. Launch of waqf insurance policy. Source: www.wakaf-alazhar.blogspot.com and https://sahabatwakaf.blogspot.com/2012/05/event-al-azhar.html

\footnotetext{
58 Interview with Ricky Dahlan, a donor and marketing person for a waqf insurance policy, 11 October 2016. Ricky is a senior marketing person at one of the national insurance companies in Indonesia, who are affiliated as supporters of the waqf of Al-Azhar. He and his wife have more than five insurance policies. He endowed one of his and his wife's future coverage money with the total amount of 1.2 billion rupiah to Wakaf Al-Azhar.

59 This is my understanding, based on Ricky Dahlan's explanation during our interview.
} 
This waqf of sharia insurance policy is a new model which is pushing beyond the conceptualized practices of waqf in regard to which it breaks from the parameters of established fiqh discourse and the institutional history of waqf. The waqf was initiated in 2012 by Muhammad Rofiq ${ }^{60}$ and one of its promotional materials speaks of "endowing a cash waqf without cash." Rofiq, who graduated from Muhammadiyah University, Jakarta is a social entrepreneur who has designed the idea of AMG and various cash waqf programs including "waqf online." Wakaf Al-Azhar has a special program called Sahabat Wakaf (Friends of Waqf), these people being marketing persons of various insurance companies who promote and offer this donation of coverage money as cash waqfs from those who purchase insurance policies from them. ${ }^{61}$ They offer AMG and other productive waqfs of Al-Azhar to be recipients of this wasiya money. In October 2016 Wakaf Al-Azhar had more than 100 policies $^{62}$ dedicated to Al-Azhar. The endowment is not yet in the form of money but, rather, certificates of life insurance from which, in 20 to 30 years, YPI Al-Azhar will receive more than 200 billion rupiahs if all of these certificates work according to plan.

The memorial garden survived a controversy and has gained support from certain 'ulama, including from Al-Azhar organization, and MUI. The Muhammadiyah organization, who initially posed strong criticism against it, has changed its position after having observed the site. Even the women's wing of Muhammadiyah, Aisyiyah, has acted in collaboration with AMG in the promoting and selling of its burial sites. Since 2011, from a total 25 hectares (that is claimed to be able to accommodate up to 29,000 bodies), six hectares has been occupied and/or purchased. ${ }^{63}$ It has facilities that include a rest area, a park, and a mosque for the care of corpses and their family members (see one of family burial cluster at figure 3). Its price is affordable for upper middle-class Muslims, being from 25 million rupiah for a single burial plot, and can even be paid in instalments via a sharia-compliant bank. At the time of writing about 1,000 burial plots in one cluster have been sold. A public relations officer of AMG, Maya Dewi, shared customer data (as at December 2016) that lower middle-income customers, bought burial plots for religious and practical reasons. ${ }^{64} 72$ per cent of its

\footnotetext{
${ }^{60}$ After having graduated from the Faculty of Islamic Studies at Muhammadiyah University, Rofiq worked in an insurance company for four years, then moved to the Dompet Dhuafa organization. In March 2018 Rofiq graduated from his Masters degree program in Islamic economics and finance at Trisakti University.

${ }^{61}$ There is a special training to become a member of Sahabat Wakaf. By October 2016 the members of Sahabat Wakaf were about 1,000 in number, of whom between 100-200 are non-Muslims. (From an interview with Suryaningsih Suyitno, coordinator of Wakaf Wasiyat Polis Asuransi Syariah, who is also coordinator of Sahabat Wakaf, October 8, 2016). See Sahabat Wakaf, https://sahabatwakaf. blogspot.it/2012/05/mitra-al-azhar.html.

${ }^{62}$ Each Friday, Al-Azhar receives about five new policies. (Suryaningsih, interview.) All policies are stored neatly in three big glass cabinets in the office of Wakaf Al-Azhar.

63 Maya Dewi, public relations officer of Al-Azhar Memorial Garden, personal communication, March 2018.

${ }^{64}$ One of the practical reasons is that they are staying in an apartment and it is difficult to find a cemetery. (M. Dewi, interview.)
} 
customers have an income between 5 to 7 million per month (these being mostly retired employees, women, aged between 53 to 63, and people who engage in religious activities once a week). About 29 per cent of its customers have an income per month between 22 to 28 million rupiah. ${ }^{65}$

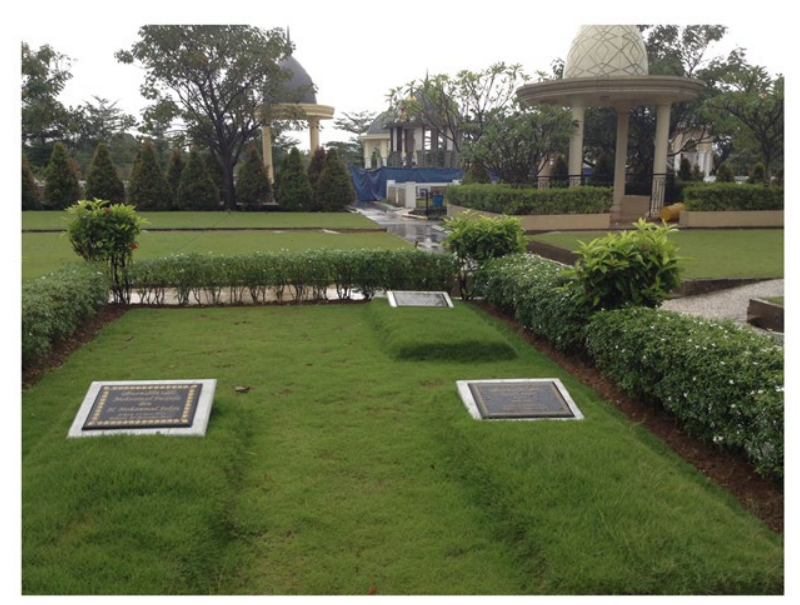

Figure 3. Burial sites at Al-Azhar Memorial Garden. Photograph by the author.

The example of AMG shows there has been an interest amongst the Muslim middle class in seeking comfortable Islamic burial sites matched by an interest in giving charity, which is the same picture as at the Firdaus Memorial Park. The new "luxurious" park concept, brought from the US, became the trigger for the birth of Muslim cemeteries that revitalized the concept of an old waqf to fit the dynamics of the neoliberal economy.

\section{Cemeteries, Waqf Productive and Transformation in Waqf-Making}

The two examples of cemeteries described above reveal a new way of endowing a waqf. The waqf-making becomes part of a purchase of burial plots, either directly and located in the same place (in the case of Firdaus Memorial Park - FMP), or indirectly, namely in a different cemetery (as in the case of Al-Azhar Memorial Garden - AMG). Each of them has a different set of complexities. The waqf-making at FMP is much simpler as it needs to change the status of purchased land to be a waqf estate. However, this may take a few years due to the bureaucratization of land procurement as it is in Indonesia. For example, from thousands of waqf cemetery plots managed by FMP, only 32 succeeded in receiving waqf certificates from the National

\footnotetext{
65 The median monthly earning in Indonesia is two and half million.
} 
Body of Land. ${ }^{66}$ The challenge for waqf-making at AMG is not land procurement and administration, ${ }^{67}$ but charity fund management (as the purchase for waqf land is taken from 50 per cent of the profits from sales). But even though the waqf cemetery for the poor has not yet been implemented, this has not affected sales since most donors place a high level of trust in the ability of YPI Al-Azhar to keep its promise as they have seen its performance over a period of time. ${ }^{68}$

The growth of the waqf movement can be seen as a consequence of various factors, namely the growth of Islamization (through piety or a pious society); a sense of philanthropization; and a developing middle-class economy. The first two factors have been explained by scholars and mentioned briefly at the start of this article. The last factor has also been discussed by several scholars ${ }^{69}$ though this has been through reference to zakat and general practices of Islamic philanthropy. Concern over the treatment of immobilized properties of waqf has become a trigger to the existing waqf movement and the innovations in cemeteries that are the focus of this essay can be seen as one result of that. The movement is supported in the main by Modernist Muslims who are well educated and who are engaged with modernist organizations, that are not Salafi in orientation, so the growing number of luxurious cemeteries (bundled with waqfs) is a consequence of urban modernist and middle-class Muslims who have made a re-reading of the old traditions in order to address those recent and current social problems that we have earlier mentioned: problems such as both the expense and the shortage of cemeteries.

The way these modernist Muslims have confronted the challenge of modern life and contemporary neoliberal economies, has not been by rejecting that modernity, but by adapting and creating modified versions that incorporate various key elements of Islamic principles, including charity. The economy of giving creates opportunities in various types of productive waqfs. For example, the Sinergi Foundation has managed two waqfs of restaurants, and other smaller shops and business. ${ }^{70}$ It also offers Muslims

66 This figure is a positive one, because for decades the number of uncertified waqf lands (shown in Table 1) has remained high, at approximately 30 per cent.

${ }^{67}$ For the land purchases of AMG, the YPI Al-Azhar collaborates with a real estate company Banyu Biru, who are also involved in the procurement of land for another luxurious burial garden. Banyu Biru is a group of real estate companies belonging to Amin Supriyadi, a businessman who dominates the real estate business in the Karawang region. These companies are also involved in the Lestari Memorial Garden. The land used for both FMP and AMG status is green land, which is not intended for buildings.

${ }^{68}$ AMG could not release its fundraising data, due to issues of confidentiality. Ricky Dahlan and all the interlocutors to whom I have spoken believe that they and YPI will achieve their aim.

69 The middle-class has been the focus of Janine Clark and Hilman Latief as one important factor in the transformation of philanthropic practices. See, J. Clark, Islam, Charity and Activism: Middle-Class Networks and Social Welfare in Egypt, Jordan and Yemen, (Bloomington, Indiana: Indiana University Press, 2004), H. Latief, "Islam and Humanitarian Affairs: the Middle Class and New Patterns of Social Activism," in Kees van Dijk and Jajat Burhanuddin (eds.), Islam in Indonesia: Contrasting Images and Interpretations, Amsterdam: Amsterdam University Press, 2013, pp. 173-194, H. Latief, Melayani Umat: Filantropi Islam dan Ideologi Kesejahteraan Kaum Modernis, (Jakarta: Gramedia, 2010a).

${ }^{70}$ Interview, Asep Irawan and HB Sungkaryo, Bandung, 26 September 2016. 


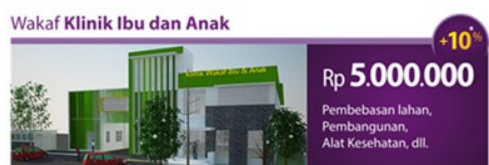

Wakaf Sawah Produktif

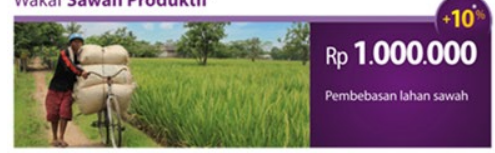

Wakaf Madinatul Qur'an (Kawasan Pendidikan Alquran)

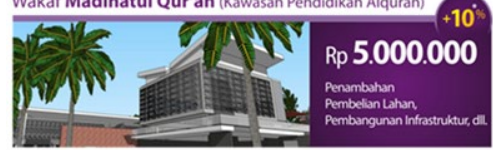

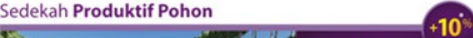

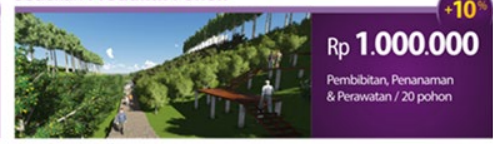

Sedekah Produktif Kambing / Domba

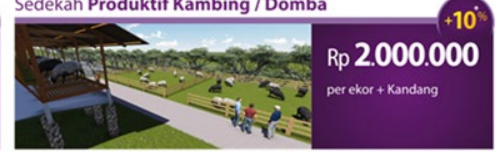

Figure 4. Products of productive waqfs offered by Sinergi Foundation. Source: Presentation on the Firdaus Memorial Park by the Sinergi Foundation, 2014.

the opportunity to endow cash waqfs with affordable amounts (see examples in figure 4) - namely from one million rupiah (USD83) - for financing many projects such as rice paddies and the "Madinatul Qur'an" (The City of the Qur'an). ${ }^{71}$ In practice, these are similar to individual donations for a joint project, of which the money is purchased for targeted objects, but they use the waqf contract (akad) and try to keep the money or objects endowed as a "corpus" which could survive forever.

Wakaf Al-Azhar also offers many types of productive waqfs. The one explained in the above section is the bundling of a waqf insurance policy with its burial sites, of which the endowed amount ranges from less than 250 million rupiahs, to 350 and 500 million, and beyond, to one billion rupiahs. In addition, it has the following six productive waqfs: 1) Waqf Khairi (from five thousand rupiahs). The larger amount of this waqf is offered by using installments through the banking system, transferred for a certain period; 2) A waqf of plantation; 3) Waqf of Properties; 4) Waqf of Transportation (a stock of 25 thousand rupiahs or two US dollars); 5) Waqf (membership) card for a family; and 6) Wakaf Online (via mobile application). ${ }^{72}$ The Wakaf Online (see its graphic user interface at figure 5 below) uses a mobile application through which the waqif could endow as little as 100 rupiah (USD 0.05) either directly or deducted from the fees of financial transactions such as an electricity bill payment. ${ }^{73}$ This application claims to be a "cash waqf without cash" (wakaf tunai tanpa uang tunai), and provides

\footnotetext{
${ }^{71}$ Interview with Asep Irawan and HB Sungkaryo, Bandung, 26 September 2016, and from the website of the Sinergi Foundation.

72 https://wakafalazhar.wakafonline.id/produk, and interviews with Rofiq Lubis, and with Suryaningsih.

73 The application is downloadable from Google play store: https://play.google.com/store/apps/ details?id=com.wazantaharrim.app\&hl=en. This application is developed by PT Taharrim Berkah Semesta.
} 


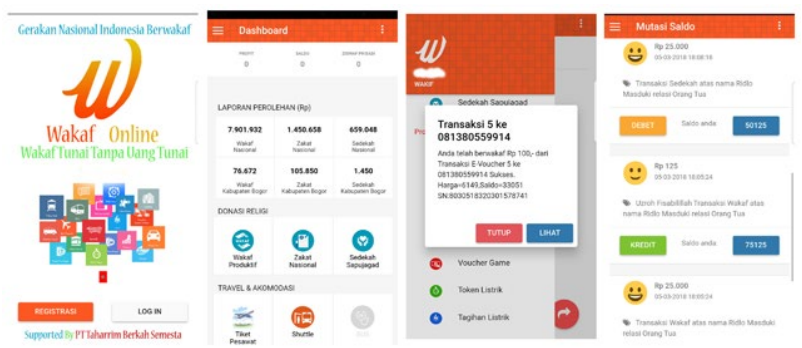

Figure 5. Wakaf Online App and examples of waqf transactions using its application. Screen shoot picture by the author.

a user (referred to as the waqif) the opportunity to give cash waqfs, zakat and sedekah and to conduct many financial transactions through the banking system. ${ }^{74}$

These various, productive waqf schemes are "friendly" to lower-income Muslims. Previously no one ever thought that they could give waqfs of 100 rupiah to an organization, but in these Islamic charitable organizations, waqf becomes both more affordable and easier. Even lower-income Muslims could make a profit by using a method such as Wakaf Online as a microfinance business to be a payment center. Islamic charitable organizations such as the Sinergi Foundation, Al-Azhar Peduli Ummat, and Dompet Dhuafa have employed the digital banking system extensively for their activities, thus bringing the old-style, charitable practices that involved large sums of money into a new format with low-cost expenses such that everyone could afford to make waqf donations.

Philanthropization, the recognition of a shortage of cemetery sites, and the economy of giving have together generated a climate of creative fundraising to tap the potential of waqf giving and assets, and Islamic philanthropy organizations have contributed in the process of transforming the waqf-making into one that involves a high level of collaboration with the financial and digital economy, and that moves the previous practice of waqf making from being confined to elite individuals or families to a position that allows lower income Muslims to be involved. The potential for this creativity exists mainly in urban middle-class communities, who are exposed to trends in the modern commercial economy.

Both the Sinergi Foundation and YPI Al-Azhar serve urban middle-income Muslims and adopt modern business practices. They contextualize hadiths, histories and accepted practices of cemeteries and of waqfs. Their innovations are put forward in consultation

\footnotetext{
${ }^{74}$ It is actually an application of the Payment Point Online Bank (PPOB), which has menus to pay zakat, waqf, and sedekah. This application - as do many PPOBs - gives profit to users (called merchants) for conducting financial transactions. With the Wakaf Online application, the profit received by merchants is referred to as charitable money and is donated to Wakaf Al-Azhar. Rofiq has explained that the system has been tested for a year and formally launched from January 2018, with total uses of about 15 thousand. Interview, 28 March 2018.
} 
with sharia advisers from their own organizations, or with individual scholars, ulama councils such as MUI, or with Islamic organizations such as Muhammadiyah. Both organizations have sought religious endorsements and have succeeded in changing the opinions of those who had previously been against the innovations. ${ }^{75}$

The ways in which Muslim charitable organizations make full use of modern, global financial systems reveal their acceptance of the realities and the effects of the neoliberal economy and, at the same time, also reveal their efforts at gaining benefit for the Muslim umma and for Islamic propagation (dakwa) - aims which they state openly. This is in line with the findings of scholars on the compatibility between Islam and the neoliberal economy with something like a form of "ethics of capitalism," or with a "pious neoliberalism" and with "market moralities" that have been discussed previously. This last concept can be seen in the choice of style adopted for the cemetery.

The cemetery styles of Firdaus and Al-Azhar show values that are common to the style applied in the San Diego Hills, as well as in Maryland's Al-Firdaus Memorial Garden. The style is the result of a combination of several aspects, from the neatness and beauty of the cemetery; from the greenery of the area; and from the interpretation of sharia compliance; and the fact that it results in being in compliance with Salafi teachings. That issue of compliance was clear in the fact that most active online narratives circulated and quoted during the controversies also referred to the concepts maintained by Salafi Muslims, namely: that there be no building above it; on the permissibility of any mound being $10 \mathrm{~cm}$ high from the ground; on having space to walk around it and on having a headstone that is simple; in its direction to the qiblab; and that it should not be mixed with non-Muslim sites. Both Firdaus and Al-Azhar, whose followers and supporters are mainly modernist Muslims, follow these lines of thought, contending that sharia compliance supported by the MUI refers to this style. ${ }^{76}$ At the same time, most cemeteries in Indonesia remain traditional in nature, with some public cemeteries not even having dedicated separate spaces for non-Muslims. ${ }^{77}$ (See Figure 6.)

Traditionalist Muslims, like those supporting the Nahdlatul Ulama organization, have no problem related to the fiqh of cemeteries that are commercial in nature yet waqf in intention, and that includes having no problems with their types and designs, saying that traditions of burial may differ between periods and places. They also respond to the commercial and luxurious cemeteries with a relaxed opinion. The chairman of the Board of Nahdlatul Ulama, Slamet Effendy Yusuf, assessed the sale

\footnotetext{
75 Discussions among 'ulama only occurred in response to the controversies.

${ }^{76}$ A long interview with the secretary of the fatwa commission at MUI re-published by Sinergi Foundation shows that the MUI concern is more with the contractual aspect and purchase or with regard to the waqf aspect of the luxurious cemeteries rather than the style of the burial plot. The secretary does not want to comment on the $10 \mathrm{~cm}$ or grassy style of the cemeteries.

${ }^{77}$ For example, a public cemetery in Cilacap District, Central Java, named "Wisma Layu Kroya," is located in a strong Nahdlatul Ulama community and does not have a separate cluster for nonMuslims. However, it does have a separate space for Javanese mystics in the back area of the cemetery.
} 


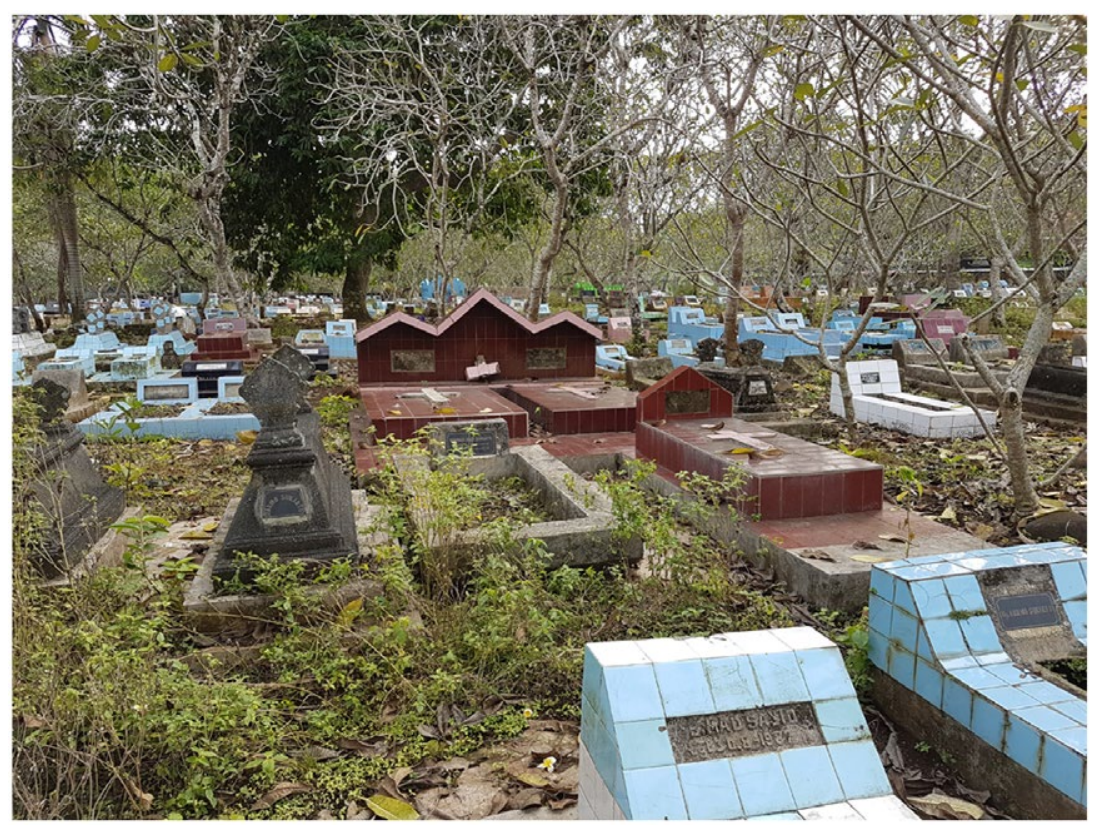

Figure 6. Public cemetery "Wisma Layu" in Kroya city in Central Java. Christian tombs are in the middle of Muslim tombs. Photograph by the author.

and purchase of land for the grave as being a mu'amala (human relations) matter: as long those involved are agreed and happy, it is no problem. ${ }^{78}$ In the same tone, Said Agiel Siraj, leader of NU, sees no problem if Muslims choose even commercial cemeteries offered by San Diego Hills, because the context of what is considered excessive or luxurious may be subjective, depending on each individual case.

In addition to the matter of interpretations of sharia compliance, both practitioners of the two memorial parks explain that the neatness and the beauty of their memorial gardens become the important aspects, as a response to the negative image of cemeteries, which tends to suggest that are untidy; that they may invoke a degree, even quite a strong degree, of fear; and that they provide no space for sitting and walking, such that other people's burial sites get trodden on. Firdaus's interlocutors have referred to criticisms from Salafi groups that many cemeteries do not accord with sharia in matters such as having building above them or being fenced. Rofiq of Al-Azhar, who is well-versed in fiqh, refers to a number of practical reasons and philosophies behind their decision on the cemetery style. He is aware of the varieties of Muslim burial

\footnotetext{
78"Menjawab Kebutuhan Umat akan Pemakaman Syariah (to answer the needs of the umma for sharia-compliance cemeteries)," Republika, Friday 27 June 2014, page accessed 10 December 2017, https://republika.co.id/berita/dunia-islam/islam-mancanegara/13/07/17/koran/khazanah-koran/ 14/06/27/n7tluq14-menjawab-kebutuhan-umat-akan-pemakaman-syariah.
} 
traditions in Indonesia, and argues that respecting someone who died does not necessarily relate to how high is his or her tombstone. The choice to use grass refers to the philosophy that this cemetery is a green and aesthetically pleasing area; one that conveys a feeling of harmony with nature and is like the neatness one finds in the complex of Indonesia's national Cemetery for Heroes (Taman Makam Pahlawan). ${ }^{79}$

Practical, aesthetic, commercial, as well as religious considerations are behind the creation of these memorial parks. As one form of new development of modern cemeteries that also provide a productive waqf, the two Muslim cemeteries that we have discussed are an innovation that use productive waqf schemes. The waqf element in both cemeteries is clearly visible, but each has a different context and scheme. Both become drivers to a new model of productive waqfs that engage modernist, middle-income Muslims but also extend an opportunity to lower-middle-income Muslim communities. The fact that the cemetery employs the same aesthetic as in the Salafi tradition does not necessarily mean that this new commercial cemetery follows that tradition. Both Firdaus and Al-Azhar cemeteries are not actively transforming the funeral tradition of the majority of Muslims, nor are they transforming the ways of waqf cemeteries. But they have contributed to the far-reaching creativities of pious neoliberals in waqf making. Philanthropization brings the old and "nonproductive" practice of waqfs to engage with modern financial practices, including embracing certain forms of architecture that seem to be relevant for middle-class Muslims. Yet even though this movement of productive waqf is strong (and is, in the case of Indonesia, supported by the government), it remains limited to the urban communities and to modernist types of Muslims, just as the circulation of productive waqfs and neoliberal economies are limited to these urban communities. In rural areas, waqf making of cemeteries endures in its traditional form.

\section{Epilogue}

This article has shown that movements in Islamic philanthropy bring innovations in ensuring the survival of the concept and practice of waqf. The economy of giving endorses innovations in "productive" waqfs, to transform the "dead," immobilized objects of waqfs in order to increase wealth. The space in which fiqh and a modernization of forms of waqf can be reinterpreted depends on the interplay between religious organizations including the ulama, and the government and positions of authority.

As one of the established charitable institutions in the Islamic tradition, waqf, in addition to zakat, will continue to be thoroughly re-imagined in its significant place within Muslim societies. With the continued growth of globalisation, the institution of waqf does not only connect and intermingle with other Muslim charitable practices, but also with other Muslim values and discourses that have circulated both in the past

\footnotetext{
${ }^{79}$ Rofiq, interview.
} 
and in the contemporary period. The circulation of teachings on waqfs should become aspects that create a common set of values and practices in any Muslim community, and the resemblances between the new waqf-cemeteries in Indonesia, such as Firdaus Memorial Garden, with the one in Maryland mentioned at the beginning is not surprising. With further globalisation, resemblances and diversities of Muslim charitable practices might increase significantly, depending on whatever is the accepted, circulated discourse and teachings. The movement of productive waqf might not be felt to be desirable by Salafi Muslims, due to the high involvement in business, and in the digital-banking system that may refer to the neoliberal economy. However, a form of Salafi-type burial used in the style of new cemeteries is not for the purpose of embracing Salafism, but is more concerned with evolving considerations of aesthetics.

Practitioners, academics as well as government believe that the assets of waqfs which are huge - could bring great public benefit, once managed professionally. Whether this idea can be achieved is subject to a number of factors, including sociopolitical issues and the state and direction of the economy. Whatever the level of success, at the very least, extensive fundraising and the creativity of Islamic charitable organizations has brought the institution of waqf and its contemporary re-imagining into "pious neoliberalism" and made it accessible to a lower middle-income population. Whatever the future, research on waqf and other forms of Islamic charities is fruitful in order "to examine the historical record of human activity and the engines of historical change." 80

\footnotetext{
${ }^{80}$ Singer, Charity in Islamic Societies, 217.
} 